Primljen / Received: 27.12.2011 Ispravljen / Corrected: 19.2.2012.

Prihvaćen / Accepted: 21.2.2012.

Dostupno online / Available online: 15.3.2012.

\title{
Analysis of pavement surface heating in urban areas
}

Preliminary note

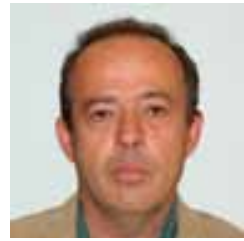

Sergije Babić, MEng. CE University of Rijeka Faculty of Civil Engineering sergije.babic@gradri.hr

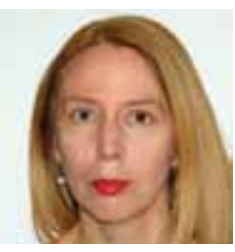

Prof. Aleksandra Deluka-Tibljaš, PhD. CE University of Rijeka

Faculty of Civil Engineering aleksandra.deluka@gradri.hr

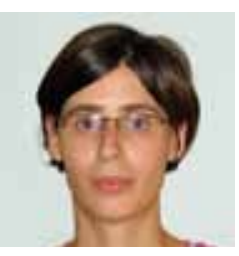

Marijana Cuculić, MEng. CE University of Rijeka

Faculty of Civil Engineering marijana.cuculic@gradri.hr

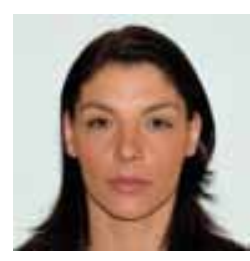

Sanja Šurdonja, MEng. CE University of Rijeka Faculty of Civil Engineering sanja.surdonja@gradri.hr
Sergije Babić, Aleksandra Deluka-Tibljaš, Marijana Cuculić, Sanja Šurdonja

\section{Analysis of pavement surface heating in urban areas}

Heat islands are areas in which temperature is higher than that prevailing in surrounding areas. They are dominantly formed in developed urban zones, and are further intensified by the use of pavement structures with poor thermal properties. Results obtained during temperature testing conducted on pavements of various types and properties are presented in the paper. The measurements were made in summer months of 2011 in the town of Rijeka. The analysis of results has revealed new data about sensitivity to heating of individual types of pavement structures, and about behaviour of various types of surfacing when subjected to similar heating conditions.

Key words:

pavement surface, heat island, asphalt, concrete, temperature

Prethodno priopćenje

Sergije Babić, Aleksandra Deluka-Tibljaš, Marijana Cuculić, Sanja Šurdonja

\section{Analiza zagrijavanja kolničkih površina urbanih područja}

Toplinski otoci su područja na kojima je temperatura viša od one u okolnom području. Nastaju uglavnom na izgrađenim površinama gradova, a doprinosi im i uporaba kolničkih konstrukcija koje imaju nepovoljnija toplinska svojstva. U radu su predstavljeni rezultati ispitivanja temperature različitih vrsta i svojstava kolničkih površna. Mjerenja su provedena tijekom ljetnih mjeseci 2011. u gradu Rijeci. Analizom rezultata je utvrđena osjetljivost pojedinog tipa kolničke površine na zagrijavanje kao i ponašanje različitih tipova površina u istim uvjetima zagrijavanja.

Ključne riječi:

kolnička površina, toplinski otok, asfalt, beton, temperatura

Vorherige Mitteilung

Sergije Babić, Aleksandra Deluka-Tibljaš, Marijana Cuculić, Sanja Šurdonja

\section{Analyse der Erwärmung von Fahrbahnoberflächen in Stadtgebieten}

Wärmeinseln sind Gebiete, in welchen die Temperatur höher ist als in den umliegenden Gebieten. Sie entstehen hauptsächlich in ausgebauten Stadtflächen, wobei die Verwendung von Fahrbahnkonstruktionen mit ungünstigen Wärmeeigenschaften dazu beiträgt. In der Arbeit werden die Resultate von Temperaturprüfungen verschiedener Arten und Eigenschaften von Fahrbahnoberflächen verglichen. Die Messungen erfolgten in der Stadt Rijeka in den Sommermonaten des Jahres 2011. Durch Analyse der Resultate wurde die Empfindlichkeit einzelner Typen von Fahrbahnoberflächen auf die Erwärmung und das Verhalten verschiedener Oberflächentypen unter denselben Erwärmungsbedingungen gemessen.

Schlüsselwörter:

Fahrbahnoberfläche, Wärmeinsel, Asphalt, Beton, Temperatur 


\section{Introduction}

Heat islands are city areas where temperatures are higher (by 1 to $3^{\circ} \mathrm{C}$ ) when compared to those prevailing in their immediate surroundings. They are dominantly developed in built-up areas of cities as a result of urbanization, which prevents natural processes of water absorption and evaporation [1]. Their development is influenced by factors that can be controlled and influenced through plans and project solutions, and by environmental and natural factors that cannot be controlled (Figure 1) [2]. The heat island effect dominantly affects urban areas where an average air temperature in the city centre in hottest months is higher than the one at city outskirts or suburbs (Figure 2).

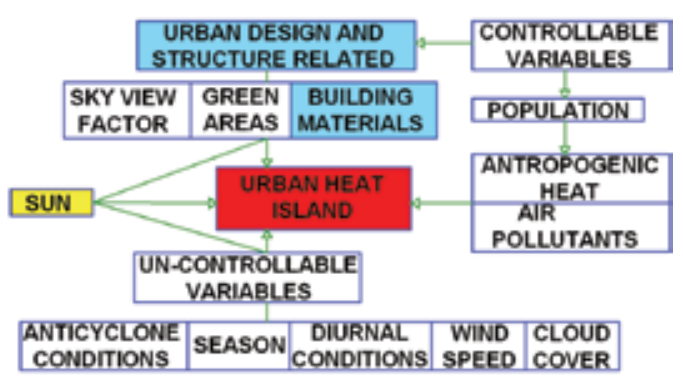

Figure 1. Urban heat island development [3]

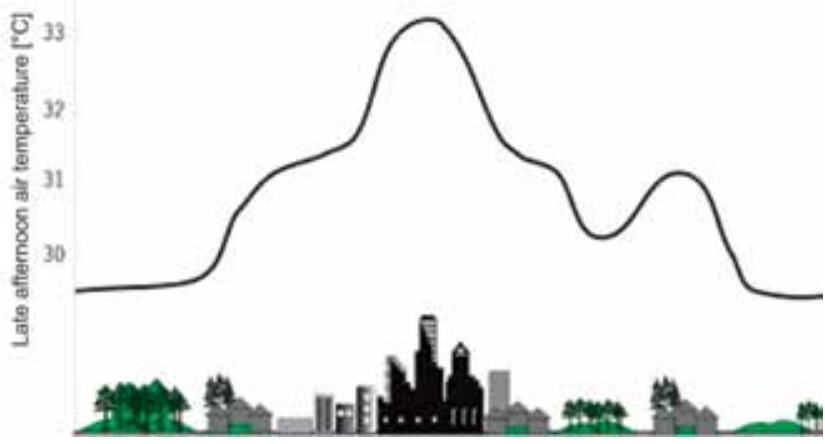

Figure 2. Diagram of temperature changes [4]

The significance of this problem is further emphasized by results of studies conducted over the last decades in Europe [4], the United States [5], Australia [6], and developed Asian countries [3]. Apart from having a harmful effect on people's life and health, higher summer temperatures in cities also bring about significant increase in energy consumption due to use of air conditioning devices. Therefore, development of heat islands is nowadays increasingly becoming an additional and highly-complex environmental issue. In order to mitigate this negative phenomenon, an increase in green surfaces and surfaces covered with water in city centres has been proposed at the urban development level. Since roofs and pavement surfaces are most exposed to thermal energy of the sun, the study of possible measures for mitigating the heat island effect is oriented towards materials and shaping of these city surfaces. The mentioned studies $[3,4,5,6]$ develop heat island effect mitigation strategies in three directions:

a) development of the so called urban forestry,

b) use of reflective materials for covering roofs, and

c) use of cool pavements and, in recent times, reflective pavements $[1,7]$.

The goal of greater use of urban forestry techniques is to increase evapotranspiration and to provide more shadowed areas in cities. It seems that European cities differ greatly as to the proportion of green surfaces in urban areas. The European average is 30 percent of green surfaces in city centre [8]. The research has shown that a strategic introduction of greenery into the cities (forestation included) could result over the next $10-15$ years in a 10 to 20 percent reduction of air conditioning costs in summer months [1]. The study conducted for the American cities (Chicago, Sacramento, Houston, and Salt Lake (ity) has shown that pavement surfaces in these cities amount to 30 to 45 percent of their overall surface, and so they are greatly responsible for air temperature increase in these cities [3]. The research has shown that the effects of urbanization and traffic development on local eco-systems (temperature included) in European cities [4] are quite alarming, and that only a few cities like Stockholm can be excluded from the general trend [9]. The research conducted by Doulos, Santamouris, and Livada, during which behaviour of 93 samples of commonly used pavement structure materials was analyzed under similar insolating conditions, has revealed which of the analyzed materials can contribute, under given micro-climate conditions (Athens, Greece), to the reduction of heat island effect and lower electricity consumption, and to the improvement of thermal conditions in open areas [10]. The same group of authors has been analyzing special materials that can contribute to lesser warming of pavement surfaces and, consequently, of the surrounding air [7]. Along with the mentioned authors, many others $[11,12]$ have been dealing with selection of the materials which, due to their optical and thermal characteristics, can have a positive effect on the environment. In order to reduce the heat island effect, they propose construction of such pavements that would allow leaking into the base, the so called porous pavements, and pavements with a more luminous surface - made of concrete or asphalt - presenting on an average lower temperatures $[2,11]$ due to their increased reflective characteristics. The mentioned pavement types are commonly called cool pavements [2].

In order to determine behaviour of commonly used pavement surface materials at maximum air temperatures and maximum exposure to insolation, a systematic measurement of pavement surface temperatures was conducted during the summer of 2011 in the city of Rijeka. From June to September, data from 40 measurement points were gathered in the city centre from surfaces made of asphalt, different 
types of stone, concrete, and concrete painted in different colours. Measurement points were located on pedestrian and pavement surfaces, and on parking lots. Measurements were conducted all day long and in periods with maximum temperatures. 80 measurements were conducted at each measurement point (more than 3000 measurements in total). Thirty-five of these measurements were full day temperature measurements (conducted on 12 July and 15 September), and the remaining ones were within the determined daily maximum values.

This paper presents the analysis of some measurement results, which are related to measurement points located on traffic surfaces at the micro-location of Riva in Rijeka. Susceptibility of specific materials to insolation, and differences between air and pavement surface temperatures, were also studied. These differences directly show negative influence of pavement surface summer temperatures on surrounding air temperatures and, consequently, on specific (built up) areas.

\section{Thermal characteristic of materials}

Heat is normally transferred in three ways [13]:

- by conduction - in solid, fluid and gaseous materials,

- by convection - in fluid and gaseous materials, and

- by radiation - in gaseous materials and in vacuum.

In pavement structures heat is transmitted by radiation. When transmitting heat by radiation, the thermal energy of a body is transformed into electro-magnetic radiation which is then transmitted by the body into its surroundings. The process is also reversible: when electro-magnetic waves reach the surface of a body, some of the waves are absorbed by the body and converted into kinetic energy, i.e. into heat [14]. Each body with a temperature of over $0^{\circ} \mathrm{K}$ radiates thermal energy in form of electro-magnetic waves, which are fully or partly converted into the inner body energy when coming into contact with other bodies. If energy $\Phi$ is radiated to a body surface (incident radiation), some of it will be reflected (rФ), some absorbed ( $\mathrm{a} \Phi)$, and the rest of the energy (d $\Phi)$ will pass through the observed body.

In that case [15] is applied:

$\mathrm{a} \Phi+\mathrm{r} \Phi+\mathrm{d} \Phi=\Phi$,

where:

a - is the absorption factor

$r$ - is the reflection factor and

$\mathrm{d}$ - is the transmission or diathermy factor

The absorbed to incident flow ratio is called the absorption factor ( $\mathrm{a} \Phi)$, and the reflection to incident flow ratio is called the reflection factor ( $\mathbf{\text { }}$ ) (cf. Figure 3). The highest amount of energy would be radiated by a body which has absorbed all the radiated energy $(\mathrm{a} \Phi=1)$ and has neither reflected $(\mathrm{r} \Phi=0)$ nor let

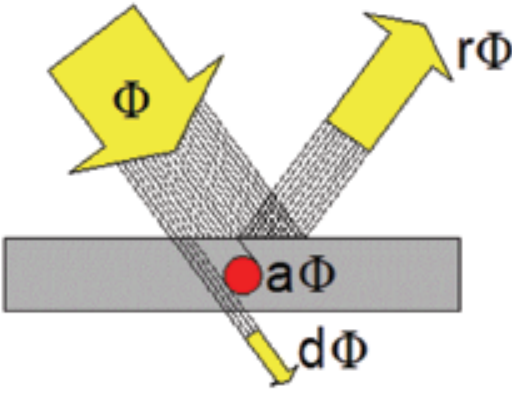

Figure 3. Absorption, reflection and transmission of radiation [14]

through $(\mathrm{d} \Phi=0$ ) any radiation. Such an ideal body is called the black body and it represents only a theoretical model that does not exist in nature. All real bodies are characterized by $\mathrm{a} \Phi<1$, that is, they will reflect $(r \Phi \neq 0)$ or let through $(d \Phi \neq 0)$ at least some of the radiated energy. The hole radiation is very close to the theoretical black body model because the incident ray is gradually absorbed at every collision with the hole surface, so that a negligibly small amount of reflected energy leaves through the small hole opening. Such a hole practically absorbs all the radiated energy, that is, it has $a \Phi=1=100 \%$. Therefore, the hole itself will transmit maximum energy just like a theoretical black body of the same temperature $(e=1)$ would do.

Solid bodies are practically impermeable to thermal radiation $(\mathrm{d} \Phi=0)$, and so the following equation is applied for such bodies.

$\mathrm{a} \Phi+r \Phi=1$.

Factors that influence warming of pavement surfaces and air above them are: solar radiation, solar reflection (albedo), and infrared radiation. The intensity of solar radiation influences temperature of pavement surface. Higher pavement surface temperature influences heat emission, which results in higher air temperature. The significance of reflective material characteristics (albedo value) is important for reducing temperature at pavement surface. Albedo is defined as the capability of surface or a body to reflect light. It is the ratio of reflected to incident electro-magnetic radiation. Albedo value of pavement surface materials, such as asphalt or concrete, ranges from 5 to 40 percent, which means that these materials absorb 95 to 60 percent of solar energy. The albedo value varies from zero for perfectly absorbing surfaces, to one for perfectly reflecting surfaces [16].

Albedo values of standard materials are shown in Table 1.

Table 1. Albedo values of standard materials [16]

\begin{tabular}{|c|c|}
\hline Material & Albedo \\
\hline asphalt & $0,05-0,20$ \\
\hline concrete & $0,10-0,35$ \\
\hline grass & $0,25-0,30$ \\
\hline trees & $0,15-0,18$ \\
\hline pavers & $0,07-0,35$ \\
\hline
\end{tabular}




\section{Analysis of pavement surface temperature measurements}

\subsection{Description of research}

The pavement surface temperature was measured at two characteristic roads in the city centre of Rijeka. The Riva Street is a major city street with intensive traffic (the AADT amounts to about 13.000 vehicles). The Riva Boduli Street is a minor street providing access to the town market. Measurement profiles were defined as road cross sections at locations which include pedestrian, driving, parking and green areas, with various final finishing levels. Measurement positions were identified by marks on the surface, taking into consideration different characteristics of materials shown in Table 2.

The pavement surface temperature was measured from 16 June to 15 September 2011. The total of some 80 measurements were made, most of which, i.e. 60 percent of individual measurements, were conducted during the previously determined time periods characterized by highest temperatures. Two whole-day measurements were also made from 7.00 a.m. to 9.00 p.m. on 12 July and 15 September 2011. In order to analyze correlations of pavement surface and air temperatures, temperatures from two neighbouring measurement points, i.e. "Transadria" (hereinafter TA) and "Nikola Tesla" (hereinafter NT), shown in Figure 4, were also recorded. The data on daily air temperature changes were recorded at measurement stations "Pehlin" and "Vežica" located at city outskirts at an altitude that is higher when compared to the level where pavement temperature measurements were made.

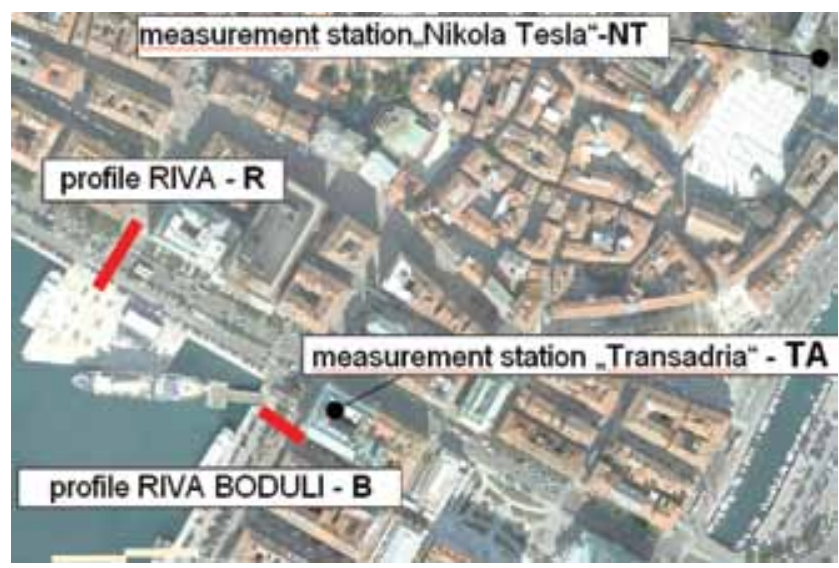

Figure 4. Riva Street and Riva Boduli Street with measurement profile position

The temperature was measured using three different portable meters ("Veleman", a no-contact infrared pocket thermometer). To provide for similar measurement conditions, portable restrainers were placed on measurement meters, and thus the same distance (about $5 \mathrm{~mm}$ ) between the device and measurement surface was obtained. Before actual recording of temperature results, two control measurements were carried out with the same equipment in order to check reliability of different measurement meters. Mean tolerance of each meter amounted to 0.1 to $0.3^{\circ} \mathrm{C}$ only, which was taken to be sufficiently reliable. Besides the temperature, the level of insolation was also recorded by $\mathrm{H}$-sign for points in the shade, and S-sign for points exposed to insolation. The level of insolation was measured in order to establish importance of points with respect to time of exposure to sun radiation.

According to measurement plan, the measurements were to be carried out on various pavement surface materials (asphalt, concrete, granite blocks, and stone), on coloured surfaces (concrete painted in various colours), and on various-use surfaces (pedestrian zones, traffic lanes, and parking lots). The plan was carried out as planned. The whole research consisted of the total of 40 measurement points. Results presented in this paper are related to measurements made at the micro-location of Riva in the city of Rijeka on traffic surfaces (traffic lanes and a parking lot). As it was established during previous measurements that the colour of material (e.g. asphalt) influences the heating level, this element was also taken into account in the course of measurements.

Figures 5 and 6 show locations of measurement points, and individual points are described in Table 2 .

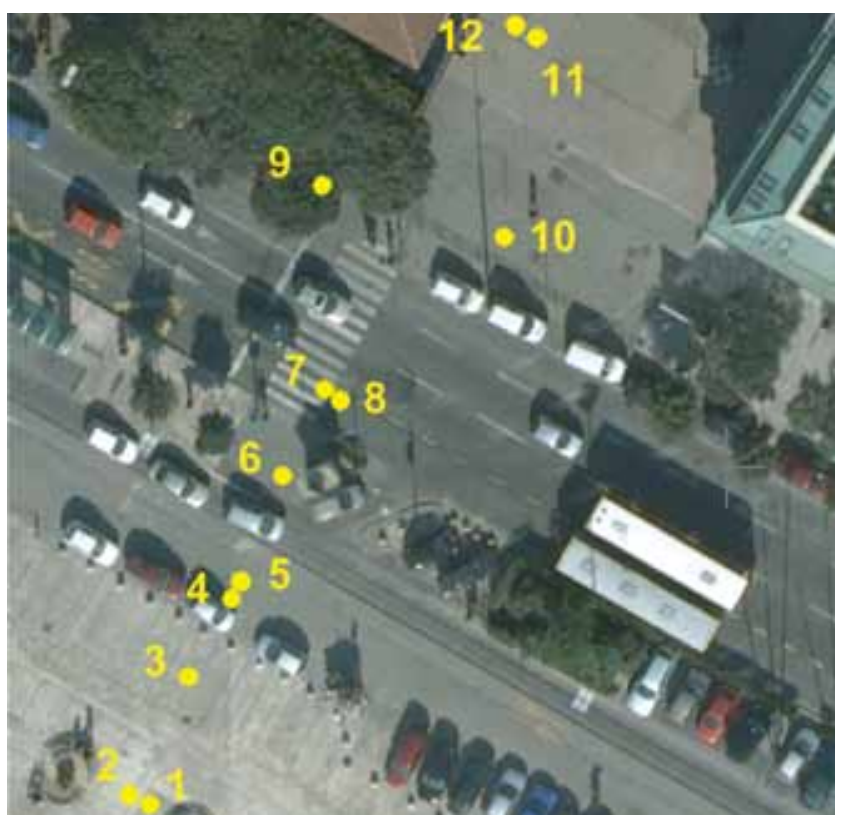

Figure 5. Measurement points at Riva Street (R)

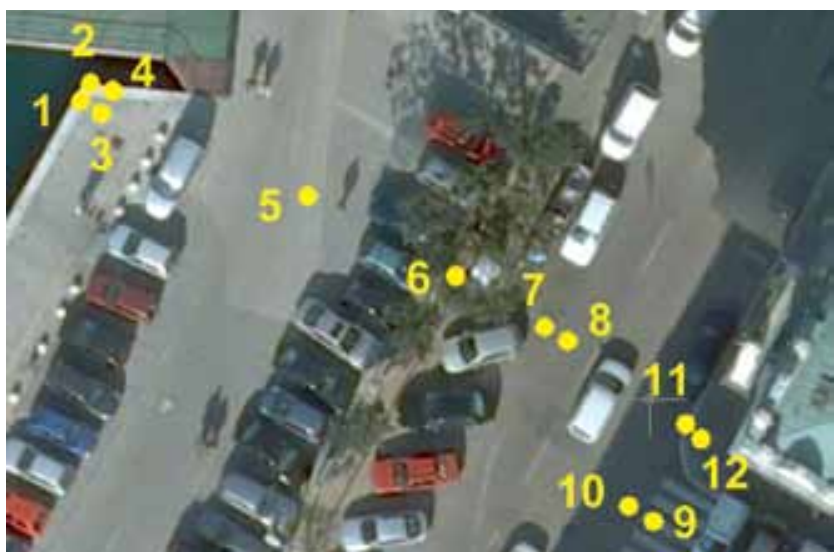

Figure 6. Measurement points at Riva Boduli (B) 
Table 2. Description of measurement points

\begin{tabular}{|c|c|c|c|}
\hline \multicolumn{2}{|c|}{ Measurement point mark } & Type of pavement surface & Use of traffic surface \\
\hline \multirow{4}{*}{ Riva Street (R) } & Point 4. (R4) & granite blocks & parking lot \\
\hline & Point 5. (R5) & asphalt & parking lot \\
\hline & Point 7. (R7) & asphalt (painted in white) & pedestrian crossing, traffic lane \\
\hline & Point 8. (R8) & asphalt & traffic lane \\
\hline \multirow{5}{*}{ Riva Boduli Street (B) } & Point 5. (B5) & concrete & traffic lane in a parking lot \\
\hline & Point 7. (B7) & asphalt & traffic lane, lighter asphalt colour \\
\hline & Point 8. (B8) & asphalt & traffic lane, darker asphalt colour \\
\hline & Point 9. (B9) & asphalt (painted in white) & pedestrian crossing, traffic lane \\
\hline & Point 10. (B10) & asphalt & traffic lane \\
\hline
\end{tabular}

\subsection{Temperature measurement results for pavement surfaces}

As previously stated, results presented in the paper are related to measurement points situated on surfaces used by motor vehicles. The measurements were made in order to establish:

- differences in behaviour of final pavement layer materials with respect to heating,

- influence of air temperature and insolation on pavement surfaces made of different materials, i.e., differences between air temperatures and different pavement surfaces and,

- other possible factors relevant to pavement surface heating (position within the traffic network, present state of e.g. asphalt base, etc.).

Results obtained by all-day temperature measurements conducted on 12 July 2011 are presented below. Results of multiple measurements conducted throughout the summer period are also presented.
The results show that, in similar micro-climate conditions, the temperature does not vary significantly when the use of pavement surface is varied (e.g. temperature variations are similar on lanes and parking lots).

3.2.1. Influence of warming on temperatures of pavement surfaces made of different materials and exposed to different insolation conditions - whole-day measurements

The study also includes analysis of behaviour of pavement surfaces made of different standard pavement asphalt and concrete materials, and granite blocks (detailed description of measurement points is presented in Table 2). Temperatures and insolation levels after whole-day measurements conducted at selected pavement surface points on 12 July are presented in Figure 7 and Table 3. The analysis of insolation also includes data on insolation at a particular location, and the rate of temperature change (warming / cooling) at a single measurement point by special shading.

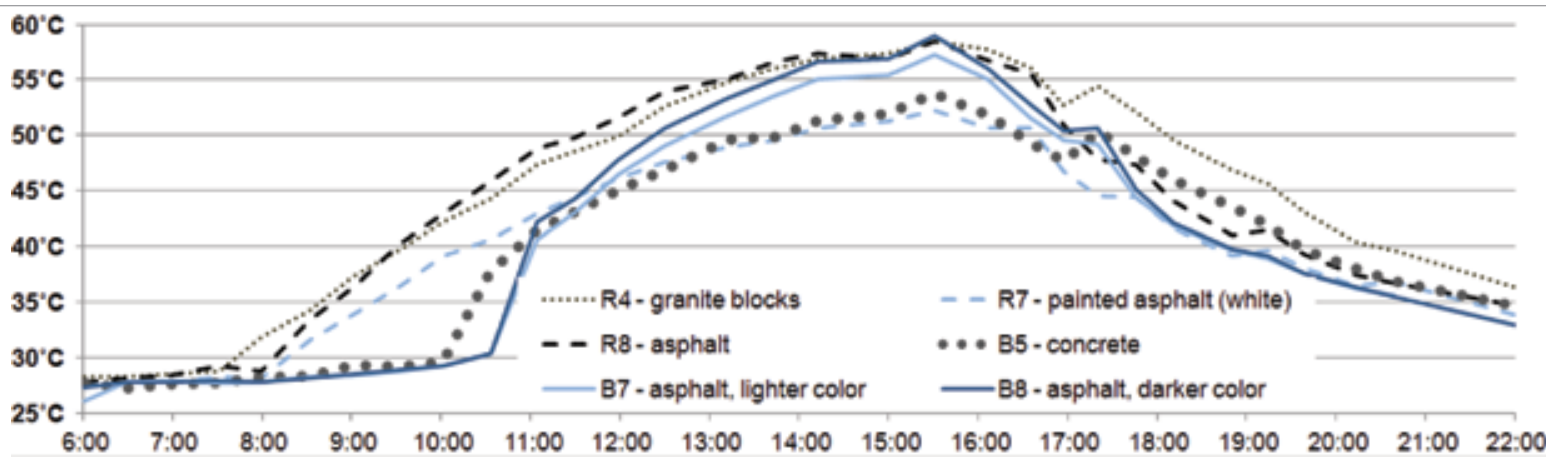

Figure 7. Whole-day pavement temperature change (on July 12 th) at selected locations

Table 3. Results of whole-day pavement temperature measurements and insolation at measurement points

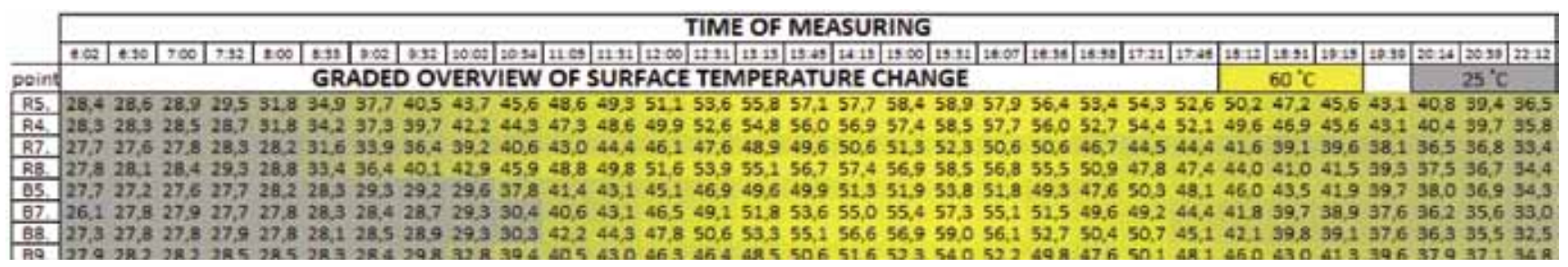


The graphic presentation of the whole-day temperature changes points to some specific features of individual pavement surface materials. It can be concluded that insolation of an individual measurement location greatly influences pavement surface temperatures, i.e., under similar insolation conditions (time period during which the surface is exposed to sunlight), different materials behave similarly in terms of temperature reached. Thus, all surfaces analyzed in this campaign reached the highest temperature at about the same time when the highest air temperature was recorded, i.e. between 3.00 and $4.00 \mathrm{pm}$.

The study also shows that under the same insolation conditions (e.g. in points $\mathrm{B} 5$ and $\mathrm{B} 8$ ), the concrete base reaches temperature that is by $5^{\circ} \mathrm{C}$ lower than the temperature of asphalt. In addition, asphalt bases of similar characteristics (primarily with regard to colour) reach very similar maximum daily temperature values regardless of time of insolation. The temperature difference between measurement points on the asphalt R5, which was insolated since 8.00 a.m., and B8, which was insolated since 11.00 a.m., amounted to only $1^{\circ} \mathrm{C}$ when the maximum daily temperature was reached. The maximum daily temperature of painted asphalt surfaces (pedestrian crossings) was by almost $6^{\circ} \mathrm{C}$ lower under the same insolation conditions. The influence of base colour was also studied during comparison of points B7 (lighter colour of asphalt) and B8 (darker colour of asphalt), which are located close to asphalt of different composition. Temperatures measured on darker material are higher by about $1^{\circ} \mathrm{C}$ to $1.5^{\circ} \mathrm{C}$ when compared to temperatures measured on a lighter surface. Temperatures of granite block base (R4) are close to those measured at asphalt (R5) under the same insolation conditions.

Figure 8 shows air temperature changes at neighbouring measurement stations "Transadria" (TA) and "Nikola Tesla" (NT), and air temperature changes at "Pehlin" and "Vežica" measurement stations that are located in a suburban area at a higher altitude. At the "Transadria" measurement point, the temperature was measured at a location that is exposed to direct sunlight. This location is also the closest to the location of pavement surface measurement points.

Figure 9 shows pavement temperature changes at two measurement points (asphalt surface in the shade (R9) and asphalt point exposed to insolation (R8), Figure 6), as compared to air temperature changes at the NT measuring station. It can be seen that temperatures at the point that is in shade all day long (R9) are lower than air temperatures, and that the difference between the temperature at this point and the one which is insolated (R8) exceeds $25^{\circ} \mathrm{C}$ when the highest daily temperature is reached.

It should be noted that the temperature at point R8, which is exposed to direct sunlight from $8.30 \mathrm{a} . \mathrm{m}$. to $7.15 \mathrm{p} . \mathrm{m}$. (with negligible shade periods), is higher than air temperature starting from about 9.00 a.m. to 10.00 p.m. when the last daily measurement was made. During this period, the difference between air temperature at the neighbouring TA measurement station and the measurement point R8 is up to $21^{\circ} \mathrm{C}$ at about 3:30 p.m., which evidently shows that pavement temperature significantly contributes to the rise in air temperature during the mentioned period of time.

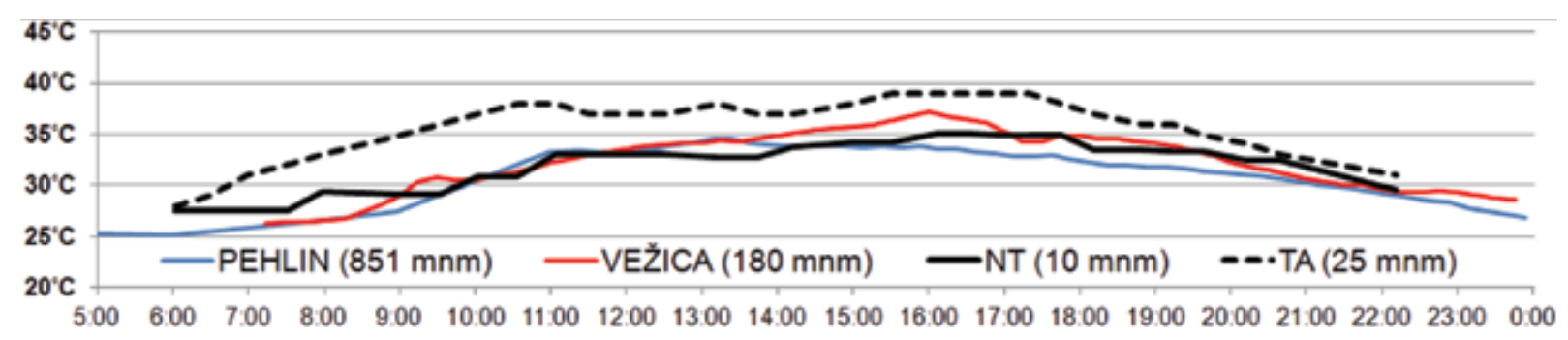

Figure 8. Air temperature changes at measurement stations on 12 July 2011

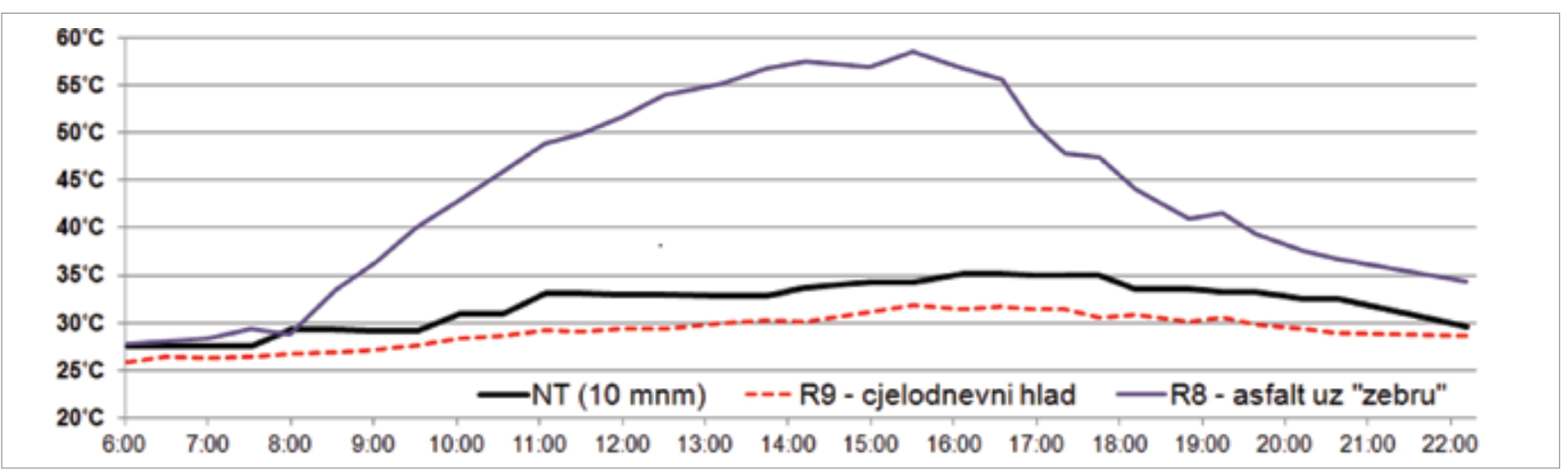

Figure 9. Pavement and air temperature changes at the NT measurement station on 12 July 2011 
3.2.2. Analysis of temperature influence on pavement surface temperature - long-lasting measurements

After the measurements were carried out in June and July either randomly or as a whole-day measurement (on 12 July), a series of measurements was conducted in August at approximately the same time (from 2:00 p.m. to 3:50 pm) when the highest air and base temperatures were recorded (Figure 10).

Figure 10 also shows temperatures measured at characteristic surfaces (asphalt, painted asphalt, and concrete) in the period from 3 August to 2 September when 16 measurements in total were made at measurement points. During the mentioned period, the air temperature varied from $26^{\circ} \mathrm{C}$ to the maximum of $37^{\circ} \mathrm{C}\left(\Delta \mathrm{t}=11^{\circ} \mathrm{C}\right)$, and the temperature of the asphalt base pavement varied from $39^{\circ} \mathrm{C}$ to $55^{\circ} \mathrm{C}\left(\Delta \mathrm{t}=16^{\circ} \mathrm{C}\right)$, with an average of $50^{\circ} \mathrm{C}\left(45.6^{\circ} \mathrm{C}\right.$ for painted asphalt).

An average difference between the air temperature and the temperature of the pavement surface at the highest temperature (asphalt) was $16.4^{\circ} \mathrm{C}$ during the mentioned period. During the same period (16 measurements during the hottest period of the day), the concrete pavement temperature was by $5.4^{\circ} \mathrm{C}$ lower than the one at the asphalt surface, and generally the same or lower than the temperature of the asphalt painted in white.

Long-lasting temperature measurements provided several atypical results. When analyzing the values measured on 18 July and 19 July, the daily maximum obtained on 19 July was by about $5^{\circ} \mathrm{C}$ lower at the same time of day. During the highest temperature, the base temperature was lower by $12-15^{\circ} \mathrm{C}$ (depending on the base) while the evening temperature was almost identical. On the very same day (and only then) the morning base temperature was higher than the maximum daily air temperature. After a closer examination of weather conditions, it became that clear some rain fell on these dates after a prolonged period with no rain, which could have had some influence on surface moisture, and hence on slower warming due to evaporation effect.

\subsection{Analysis of infra-red photos taken at measurement locations}

Infra-red (IC) photos of measurement locations at the Riva Street micro-location (Figure 5) clearly indicate that there is a difference in temperature between the point itself and the surrounding surface. Even the same material of different

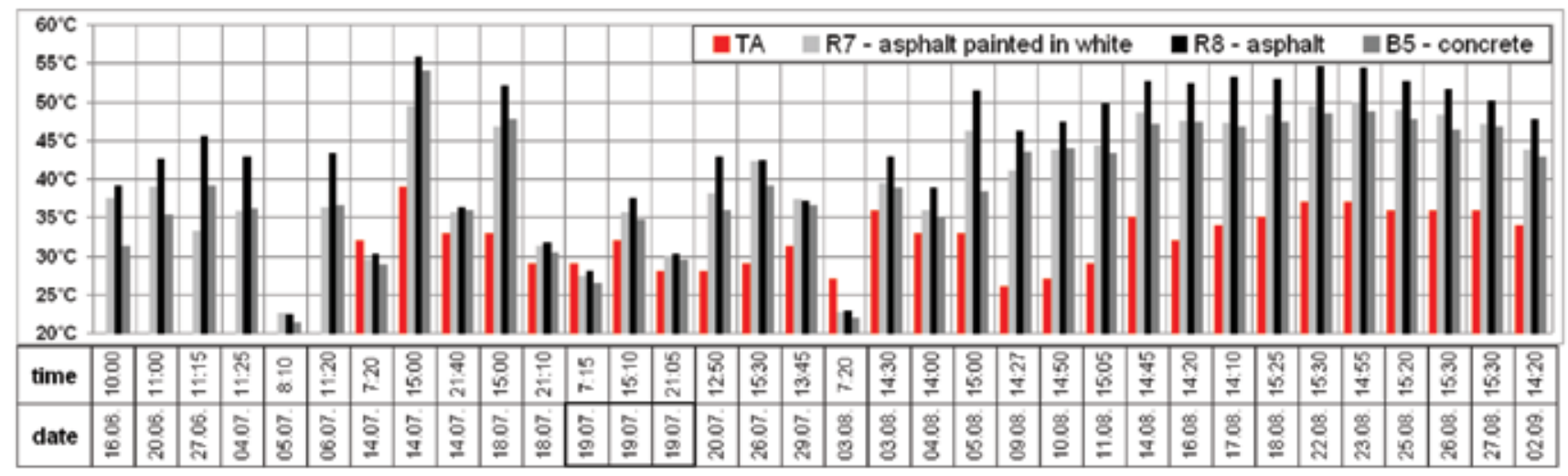

Figure 10. Overview of air temperatures and temperatures of different bases - measurements carried out from June to August 2011

Table 4. Overview of measurement points at the Riva Street micro-location with its IC photo

\begin{tabular}{|l|l|l|}
\hline Description of the point & & \\
\hline $\begin{array}{l}\text { Point 4. (R4) } \\
\text { Granite blocks at the parking lot }\end{array}$ \\
\hline $\begin{array}{l}\text { Point 5. (R5) } \\
\text { Asphalt touching granite blocks at the parking lot }\end{array}$ \\
\hline $\begin{array}{l}\text { Point 7. (R7) } \\
\text { Asphalt - white stripe of pedestrian crossing }\end{array}$ \\
\hline $\begin{array}{l}\text { Point 8. (R8) } \\
\text { Asphalt - traffic lane }\end{array}$
\end{tabular}


colour, in this case, asphalt and asphalt painted in white (points R5 and R7), can exhibit differences in temperature (for about $4^{\circ} \mathrm{C}$ ) at the same micro-location. The photo of the measurement location R4, where granite blocks bound with bitumen are shown, clearly shows the difference in temperature of these materials, which is by no means negligible (Table 4).

\section{Conclusion}

Development of heat islands as areas where temperatures are higher when compared to those registered in areas around city centres during summer, is recognized as one of important environmental issues because it negatively influences standard of living and health of city residents, and increases energy consumption. The analysis of factors influencing development of heat islands in the cities shows that excessive construction has significantly contributed to the development of this negative phenomenon. Because of area they occupy in city centres, traffic surfaces are recognized as an important element for increasing or abating this phenomenon. When planning and designing traffic surfaces in the city, the heat island mitigation strategy must also include usage of materials with high albedo (so called cool pavements), construction of porous pavements of different materials (especially at parking lots and pedestrian surfaces), and properly planned road forestation.

This paper presents some of the results obtained during the pavement surface temperature study conducted in the city of Rijeka in the summer of 2011. The results indicate that the warming of pavement surfaces greatly influences temperature of surrounding areas because they show a difference in air and surface temperature. It can be concluded that asphalt is the most unfavourable material when taking into account its thermal characteristics. It must also be pointed out that the colour of material plays an important role even in case of materials with unfavourable characteristics. Therefore, a lighter asphalt or the one painted in white has more favourable thermal characteristics than the darker (renewed) asphalt surfacing. Concrete is less hot than asphalt both in maximum and constantly high (summer) temperatures, which makes it more favourable for use in cities with regard to its warming properties. Further research must concentrate on characteristics of built in materials, such as the colour and texture, and on possibilities for comparing standard pavements with the previously mentioned porous pavements under the same warming conditions.

\section{REFERENCES}

[1] Golden, J.S.: The Built Environment Induced Urban Heat Island Effect in Rapidly Urbanizing Arid Regions - A Sustainable Urban Engineering Complexity, Environmental Sciences, Vol. 1 (2004), No. 4, pp. 321-349.

[2] Cuculić, M.; Šurdonja, S.: Pregled novijih kolničkih konstrukcija koje ublažavaju efekt urbanih toplinskih otoka, Zbornik radova Sveučilišta u Rijeci, knjiga 13 (2010), 245-262.

[3] Memon, R.A.; Leung, D.Y.C.; Chunho, L.: A review on the generation, determination and mitigation of the Urban Heat Island, Journal of Environmental Sciences, Vol. 20 (2008), No. 1 , pp. 120-128.

[4] Santamouris, M.: Heat Island Researc in Europe: State of the Art, Advances in Building Enenrgy Research, Vol. 1 (2007), No. 1, pp. 123-150

[5] United States Environmental Protection Agency, EPA`s Report on the Environment, EPA, Washington DC, 2008.

[6] Torok, S.J.; Morris, C.J.G.; Skinner, C.; Plummer, N.: Urban heat island features of southeast Australian towns, Australian Meteorological Magazine, Vol. 50 (2001), No. 1, pp. 1-13

[7] Santamouris, M.; Synnefa, A.; Karlessi, T.: Using advanced cool materials in the urban built environment to mitigate heat islands and improve thermal comfort conditions, Solar Energy, Vol. 85 (2011), No. 12, pp. 3085-3102.
[8] Konijnendijk, C.C.: A decade of urban forestry in Europe, Forest Policy and Economics, Vol. 5 (2003), No. 2, pp. 173-186.

[9] Bolund, P., Hunhammar, S.: Ecosystem services in urban areas, Ecological Economics, Vol. 29 (1999), No. 2, pp. 293-301.

[10] Doulos, L.; Santamouris, M.; Livada, I.: Passive cooling of outdoor urban spaces. The role of materials, Solar Energy, Vol. 77 (2004), No. 2, pp. 231-249.

[11] Nakayama, T.; Fujita, T.: Cooling effect of water-holding pavements made of new materials on water and heat budges in urban areas, Landscape and Urban Planning, Vol. 96 (2010), No. 2, pp. 57-67.

[12] Synnefa, A.; Dandou, A.; Santamouris, M.; Tombrou, M.: On the Use of Cool Materials as a Heat Island Mitigation Strategy, Journal of Applied Meteorology and Climatology, Vol. 47 (2010), No. 11, pp. 2846-2856.

[13] Šimetin, V.: Građevinska fizika, Fakultet građevinskih znanosti Sveučilišta u Zagrebu, Zagreb, 1983.

[14] Kulišić, P.: Mehanika i toplina, Školska knjiga, Zagreb, 2005.

[15] Lazić, L.: Numeričke metode u toplinskoj analizi, Metalurški fakultet, Sisak, 2007

[16] United States Environmental Protection Agency, Reducing Urban Heat Islands: Compendium of Strategies Cool Pavements, EPA, Washington DC, 2008. 